\title{
The impact of cattle and sheep grazing on grassland in Vel'ká Fatra National Park
}

\author{
Stela JENDRIŠÁKOVÁ, Zuzana KOVÁČIKOVÁ, \\ Vladimíra VARGOVÁ, Milan MICHALEC
}

Plant Production Research Centre Piešt'any - Grassland and Mountain Agriculture Research Institute Banská Bystrica, Mládežnícka 36, 97421 Banská Bystrica, Slovakia; e-mail: jendrisakova@ vutphp.sk

\begin{abstract}
The Vel'ká Fatra National Park (declared on 1 April 2002) is extending on an area of 40,371 ha and was established to protect well-preserved ecosystems. The Vel'ká Fatra (Greater Fatra) with the highest peak Ostredok (1592 m altitude) is a typical mountain territory and ranks among the highest mountain ranges in Slovakia. Grassland areas above the forest line ("hole" in Slovak) and highland relief are typical for Vel'ká Fatra where forests cover is $85 \%$ of the area. Large areas of grassland located on gently modelled ridges resulted from deforestation many centuries ago. The alpine meadows which are rich in rare plant communities cover the area of 2000 ha. In the past, these grasslands were used by cutting and grazing. Nowadays, the meadows are not mowed at all. The reasons are low numbers of ruminants in nearby farms, high cost and poor access roads that are eroded very much. Grazing with young cattle has been banned and consequently tall grasses expanded, swards thinned as well as avalanche risk increased. Currently, it is allowed to graze young cattle again, but farmers do not exploit this option very much. About 200 heifers and 2,500 sheep graze there, but only at the lowest areas of the mountains and for short periods of time. The grassland is dominated by Deschampsia caespitosa (L.) P. Beauv. and also by very rapidly expanding Calamagrostis epigejos (L.) Roth, Brachypodium pinnatum (L.) P. Beauv. and Cirsium arvense (L.) Scop. indicating a prolonged period of abandonment.
\end{abstract}

Key words: grazing, alpine grassland, cattle, sheep, botanical composition

\section{INTRODUCTION}

In the past, grasslands in the Vel'ká Fatra National Park were used by cutting and grazing. Nowadays, the area of 2,000 ha of mountain subalpine meadows are not cut at all. The reasons are low numbers of ruminants in nearby farms, high costs associated with the utilization of these swards and poor access roads that are eroded very much. Grazing with young cattle has been banned and consequently tall grasses expanded, swards thinned as well as avalanche risk increased (40 to 
200 avalanches occur each year). Currently, it is allowed to graze young cattle again, but farmers do not exploit this option very much. About 200 heifers and 2,500 sheep graze there, but only at the lowest areas of the mountains and for short periods of time.

In 2010, we have initiated the project entitled "Grassland Management Handbook - Ungulate Game and Favourable Welfare Conditions for Black Grouse in Alpine Areas" in cooperation with the National Forest Centre in Zvolen. It aims to create favourable conditions for the habitats of black grouse and ensure quality and nutritive pasture swards for ungulate game, while improving landscape formation processes.

\section{RESEARCH AREA}

The Vel'ká Fatra National Park is located in the north-western part of central Slovakia. It stretches over the regions of Turiec, Liptov and Banská Bystrica, ranking among the greatest and highest mountain ranges in Slovakia. The locality of Krížna - Král'ova Studňa (altitude 1,277-1,400 m) was one of the areas grazed with heifers.

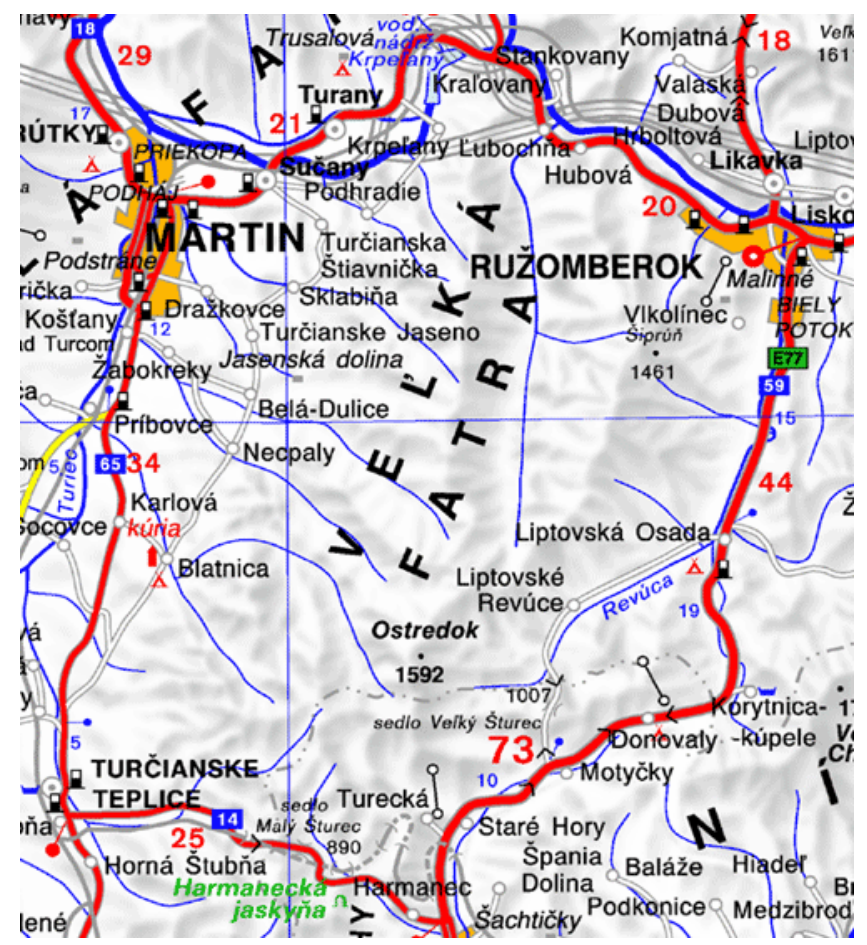

Fig. 1. Map of the Vel'ká Fatra Mountain Range 
Highland relief is typical for rounded, softly modelled mountain ridges. In areas above the forest line ("hole" in Slovak) in the Vel'ká Fatra mountain range, avalanche gullies are the most attractive from botanical point of view. Avalanches, typical for this mountain range and occurring on a regular basis, they have proved to be one of ecological factors. Unique habitats within avalanche gullies are characterized by a great variety of species and rare plants, for instance, Astragalus species. Also some thermophilic species grow at these altitudes, as Origanum vulgare L. or Digitalis grandiflora Mill. (KoŠŤÁL, 2010).

\section{RESEARCH METHODS}

The monitoring of the study area was performed in 2010. It includes: botanical composition of permanent grassland, herbage qualitative parameters, soil qualitative parameters and the state of permanent grassland utilization. The study area was divided into three parts. The first one was non-utilised; the second one - utilised by grazing and folding in the past; and the third one - utilised by grazing in present.

The botanical composition of grassland in Králova Studňa was assessed with the method of projective dominance by Maloch. Forage value was determined with the method of grassland quality evaluation $\left(\mathrm{E}_{\mathrm{GQ}}\right)$ according to NOVÁK (2004). The quality of herbage was determined by laboratory analyses of the samples sampled during the growing season. Forage samples were analysed for nutrient content in accordance with the Regulation No. 2145/2004 of the Ministry of Agriculture of the Slovak Republic. Nutritive value of the forage was calculated after the completion of laboratory analyses in accordance with the Regulation No. 39/2/2002-100 of the Ministry of Agriculture of the Slovak Republic.

\section{RESULTS AND DISCUSSION}

The transformation of Fatra forests began with the migration of population to mountain areas. In the $17^{\text {th }}$ century, it was brought about by the Wallachian colonisation which refers to the spread of shepherds from Romania across the Carpathian arch to our region. Monarchs granted the right to shepherds to deforest the summit areas of the Vel'ká Fatra mountain range. By cutting down the trees and burning up the land, shepherds created new mountain pastures for their flocks of sheep and goats. Shepherding in the Vel'ká Fatra mountain range culminated about 75 years ago when several tenths of shepherd farms were located in this area. Besides sheep, heifers and horses pastured on pastures above the forest line, which was typical mainly for the areas of Ploská and Minčol. Meadow management blossomed as well. During the first years since the collectivisation, the importance of sheep and shepherding was underestimated. As late as in 1972, following the socialisation of 
agriculture, one of the largest modern sheep farms in Slovakia was established in Liptovské Revúce.

The botanical composition of the non-utilised part of grassland (1) shows that the botanical group of grasses $(77 \%)$ had the highest proportion. The sward was dominated by Carex serpervirens L. (34\%), Briza media L. (24\%) and Lolium perenne L. (19\%). The botanical group of herbs was represented with $22 \%$. The highest abundance had Alchemilla vulgaris L. and Hypericum montanum L., $4 \%$ each. The presence of legumes was only $1 \%$ (Trifolium repens L.). Permanent grassland utilised by grazing and folding in the past (2) has the following botanical composition: $25 \%$ grasses, $52 \%$ forbs and $22 \%$ legumes. The greatest presence out of grass species had Briza media L. (18\%), out of herbs Alchemilla vulgaris L. and Galium cruciata L. (8\% each), and Vicia cracca L. (22\%). Permanent grassland utilised by grazing nowadays (3) were characterized by the $85 \%$ presence of grass species (dominant Deschampsia caespitosa (L.) P. Beauv. 65\%) and the $15 \%$ presence of herbs (Alchemilla vulgaris L. 6\%).

The intensity and method of grassland utilization are reflected in the floristic composition. By employing optimum intensity and appropriate utilization methods, or mosaics utilization of sites (e.g alternating among more extensive and intensive grazing and cutting methods), the species-rich communities comprising many rare and endangered or threatened species can be maintained on a long-term basis. Land abandonment or too low utilization intensity lead to spontaneous succession of the vegetation in which woody vegetation or some expansive grass species re-occupy former farm land (SLÁVIKOVÁ, KRAJČOVIČ, 1998). JANČOVIČ and VOZÁR (2004) include non-utilised grassland into the category defined by colonization with woody plants or single trees and shrubs at various levels, and into the category of non-utilised, often abandoned and neglected grassland at various levels of extensification. The second category covers different semi-natural grassland types of various vegetation levels where the natural succession occurs gradually following the exclusion of cutting or managed grazing (return to forest formation), without human intervention. Changes in the diversity of the semi-natural grassland from peat soil that is following after the diminishing of the use intensity or complete absence of management were assessed by MLYNARCZYK et al. (2002). In his work, they are characterized mainly by the decline in cover of valuable grass and legume species, while percentage cover of marsh plant species increased.

Grassland abandonment determinates the fast spread of Deschampsia caespitosa (L.) P. Beauv., Calamagrostis epigejos (L.), Brachypodium pinnatum (L.) P. Beauv. and Cirsium eriophorum (L.) Scop., which can suppress the growth of other high valuable species of short - mainly stoloniferous - grass species, legumes and medicinal herbs. As shows their forage value, such swards have poor quality. In 2010, grassland quality evaluation $\left(\mathrm{E}_{\mathrm{GQ}}\right)$ ranged between 15.2 and 38.5 throughout the growing season. According with these values, the sward can be included in the 
category of low to lower value grassland. Valuable swards start at the value $\mathrm{E}_{\mathrm{GQ}}=$ 70 .

It was found that grassland dominated by Deschampsia caespitosa (L.) P. Beauv. was utilised by sheep grazing in early spring. In this period, the mean values of the crude protein content of the analysed phytomass samples ranged 104.47 $\mathrm{g} \cdot \mathrm{kg}^{-1}$ dry matter (DM), and of crude fibre content $258.78 \mathrm{~g} \cdot \mathrm{kg}^{-1} \mathrm{DM}$. An average digestibility coefficient was approximately $62.05 \%$, digestible protein in the intestine (PDI) $65.12 \mathrm{~g} \cdot \mathrm{kg}^{-1}$, metabolisable energy (ME) $9.41 \mathrm{MJ} \cdot \mathrm{kg}^{-1}$, brute energy (BE) $18.58 \mathrm{MJ} \cdot \mathrm{kg}^{-1}$, net energy for lactation (NEL) $5.50 \mathrm{MJ} \cdot \mathrm{kg}^{-1}$, net energy for fattening (NEF) $5.27 \mathrm{MJ} \cdot \mathrm{kg}^{-1}$ at the DM content $276.20 \mathrm{~g} \cdot \mathrm{kg}^{-1}$ in $1 \mathrm{~kg}$ fresh fodder.

In later period, the sward was grazed selectively; e.g. sheep did not graze on Deschampsia caespitosa (L.) P. Beauv. In this period, content of dry matter (DM) and crude fibre in the forage was $69.24 \mathrm{~g} \cdot \mathrm{kg}^{-1}$ and $269.02 \mathrm{~g} \cdot \mathrm{kg}^{-1} \mathrm{DM}$ respectively. An average digestibility coefficient was $57.50 \%$, protein digestible in the intestine (PDI) $43.16 \mathrm{~g} \cdot \mathrm{kg}^{-1}$, metabolisable energy (ME) $9.43 \mathrm{MJ} \cdot \mathrm{kg}^{-1}$, brute energy (BE) $18.47 \mathrm{MJ} \cdot \mathrm{kg}^{-1}$, net energy for lactation (NEL) $5.54 \mathrm{MJ} \cdot \mathrm{kg}^{-1}$, net energy for fattening (NEF) $5.37 \mathrm{MJ} \cdot \mathrm{kg}^{-1}$ at the DM content $644.34 \mathrm{~g} \cdot \mathrm{kg}^{-1}$ in $1 \mathrm{~kg}$ fresh fodder.

These results correspond with the values reported by GÁLIK et al. (2010). Mean digestibility coefficients of hay ranged between 49.08 and $53.68 \%$. As for hay, negative correlation was found between nutrient digestibility and DM content. The content of crude protein $\left(311.8 \mathrm{~g} \cdot \mathrm{kg}^{-1} \mathrm{DM}\right)$ was higher, and at the same time, a lower digestibility coefficient of organic matter (49.08\%) was determined.

Forage nutrient digestibility can be considered a limiting factor of forage quality. It expresses the proportion among the nutrient content of the feed and its actual utilization by ruminants (PAJTÁš et al., 2009). When producing grass-based hay, a growing season of dominant grass species should be taken into account in order to determinate the optimal time for the harvesting. Intensive lignification usually occurs after flowering and determinates in low nutrient digestibility (GÁLIK et al., 2010).

Metabolisable energy (ME) of forage from grassland was $9.41 \mathrm{MJ} \cdot \mathrm{kg}^{-1}$; net energy for lactation (NEL) $5.50 \mathrm{MJ} \cdot \mathrm{kg}^{-1}$; and net energy for fattening (NEF) 5.28 $\mathrm{MJ} \cdot \mathrm{kg}^{-1}$.

Table 1. Soil parameters

\begin{tabular}{l|c|c|c|c|c|c}
\hline \multicolumn{1}{c|}{ Site } & $\begin{array}{c}\text { Depth } \\
\mathrm{mm}\end{array}$ & $\mathrm{pH}_{\mathrm{KCl}}$ & $\begin{array}{c}\text { Humus } \\
\mathrm{g} \cdot \mathrm{kg}^{-1}\end{array}$ & $\begin{array}{c}\mathrm{N} \\
\mathrm{g} \cdot \mathrm{kg}^{-1}\end{array}$ & $\begin{array}{c}\mathrm{P} \\
\mathrm{mg} \cdot \mathrm{kg}^{-1}\end{array}$ & $\begin{array}{c}\mathrm{K} \\
\mathrm{mg} \cdot \mathrm{kg}^{-1}\end{array}$ \\
\hline $\begin{array}{l}\text { Non-utilised } \\
\begin{array}{l}\text { Utilised by grazing } \\
\text { and folding in the past }\end{array}\end{array}$ & $0-100$ & 6.87 & 149.68 & 10.77 & 4.51 & 87.79 \\
$\begin{array}{l}\text { Utilised by grazing in } \\
\text { present }\end{array}$ & $0-100$ & 6.83 & 176.90 & 10.66 & 7.12 & 110.69 \\
\hline
\end{tabular}


Non-utilised grassland and grassland utilised by grazing and folding in the past have neutral soil reaction. Grassland utilized by grazing in present has extremely acid soil reaction. Humus content is medium in all swards and this can have a positive impact on the retention capability of grassland. Phosphorus content is very low in all sites. Potassium content is medium in non-utilised grassland and grassland utilised by grazing and folding in the past and good in grassland utilised by grazing in present.

Inappropriate grazing management in the past determined the occurrence of Deschampsia caespitosa (L.) P. Beauv., which is the dominant species in most of the sites. Deschampsia caespitosa (L.) P. Beauv. is one of the most troublesome weed species in meadows and pastures. It has a very low digestibility coefficient due to its rough-textured leaves and solid stems, and it is usually avoided by grazing animals. Moreover, its dense tussocks make it difficult to cut. Deschampsia caespitosa (L.) P. Beauv. is also considered a dangerous forest weed due to its dense tussocks which hinder natural regeneration (REGAL and ŠINDELÁŘOVÁ, 1970).

Also, the presence of Calamagrostis epigejos (L.) in meadows and pastures is surely evidence of insufficient sward utilization. It is rough, hardly palatable grass species with no value for forage purposes. Brachypodium pinnatum (L.) P. Beauv. is an indicator species of calcareous subsoil. Its herbage is rough and coarse with a low digestibility coefficient.

Areas, where farms and sheepfolds were once located, are nowadays monoculture swards of Rumex alpinus L. and Urtica dioica L. (MICHALEC et al., 2010).

\section{CONCLUSIONS}

Non-utilization or insufficient utilization of permanent grassland in the Vel'ká Fatra National Park results in fast spread of Deschampsia caespitose (L.) P. Beauv., Calamagrostis epigejos L., Brachypodium pinnatum (L.) P. Beauv. and Cirsium eriophorum (L.) Scop. which can suppress the growth of other high value species of short - mainly stoloniferous - grass species, legumes and medicinal herbs. Such swards have poor quality. Their quality according to the grassland quality evaluation $\left(\mathrm{E}_{\mathrm{GQ}}\right)$, ranging between 15.2 and 38.5 , indicates that they fall within the category of low to lower value swards.

Crude protein content ranged $104.47 \mathrm{~g} \cdot \mathrm{kg}^{-1} \mathrm{DM}$, and fibre content 258.78 $\mathrm{g} \cdot \mathrm{kg}^{-1} \mathrm{DM}$. An average digestibility coefficient was approximately $62.05 \%$.

The soil analyses showed that the content of basic nutrients $(\mathrm{N}, \mathrm{P})$ was low and potassium and humus content was medium. Non-utilised grassland and grassland utilised by grazing and penning in the past have neutral soil reaction while grassland utilised by grazing at present has extremely acid soil reaction. 
In 2010, at highest altitudes from 1,000 to $1,500 \mathrm{~m}$, grassland was utilised only by grazing with heifers. Sheep grazed in areas of lower altitudes. The reasons for this unfavourable state include low numbers of ruminants in nearby farms, high costs associated with the utilization of these swards, poor access roads and nonprofessional or sporadic conservation interventions concerning the utilization or non-utilization of grassland.

It should be the obligation of the present generation to maintain sustainable landscape. Success in achieving sustainability is dependent on appropriate management systems which, as a result, can lead to improved quality of life. Grassland exploitation in the Vel'ká Fatra Mountain Range must be essentially changed namely on the basis of the latest scientific knowledge.

\section{ACKNOWLEDGEMENTS}

This work was supported by the EU Operational Programme "Research and Development", ITMS 26220220042, "Grassland Management Handbook - Ungulate Game and Favourable Welfare Conditions for Black Grouse in Alpine Areas", co-financed by the European Regional Development Fund.

\section{REFERENCES}

1. Gálik B., Bíro D., JurÁČek M., Šimko M., Rolinec M., 2010. Nutritive value and in vitro digestibility. (in Slovak). In VIII. Zjazd Slovenskej spoločnosti pre pol’nohospodárske, lesnícke, potravinárske a veterinárske vedy pri SAV: Zborník prednášok, Nitra: Slovenská pol’nohospodárska univerzita: $144-148$.

2. JANČOVIČ J., VOZÁR L., 2004. What to do with grasslands which are not use for forage production. (in Slovak). Naše pole, 8, 8: 24-25.

3. KoŠŤÁL J., 2010. Flora. The natural beauty of Slovakia edition. (in Slovak). Dajama, Bratislava: $1-128$.

4. Michalec M., Jendrišáková S., VARgOvá V., KovÁČIKovÁ Z., 2010. Changes in grassland utilization in Slovakia. (in Slovak). In: Kvalita píce z trávních porostů a chov skotu v měnících se ekonomických podmínkách: sborník z celostátní vědecké konference $\mathrm{s}$ mezinárodní účastí, Praha: VÚRV, v.v.i.: 11-23.

5. MlynarCZyK K., MARKS E., Korona A., 2002. Changes in meadow plant associations under extensive management. In: Multi-Function Grasslands, Quality Forages, Animal Products and Landscapes. La Rochelle, France- EGF Grassland Science in Europe, 7: 814-815.

6. NovÁK J., 2004. Evaluation of grassland quality. Ekológia, 23, 2: 127-143.

7. PAJTÁŠ M., Biro D., HorniakovÁ E., BeŇUŠKa N., ŠIMKO M., JuRÁČEK M., 2009. Animal nutrition and feeding: terminological dictionary. (Slovak) 1. vyd. Nitra: Slovenská pol'nohospodárska univerzita: $1-150$.

8. Regal V., ŠindelÁŘovÁ J., 1970. The atlas of the most important grasses. (in Czech). Státní zemědelské nakladatelství Praha: 1-106.

9. SláViKová D., KRAJČOVIČ V., 1998. Biodiversity protection in the Protected Landscape Area - Biosphere Reserve Pol'ana and management of its grasslands 2. Bratislava, IUCN: 1-205. 


\section{STRESZCZENIE}

\section{Wpływ wypasu bydła i owiec na ekosystemy trawiaste Parku Narodowego Vel'ká Fatra}

Słowa kluczowe: bydło, tqki alpejskie, owce, skład botaniczny, wypas

Park Narodowy Vel'ká Fatra ustanowiony 1 kwietnia 2002 r. dla ochrony dobrze zachowanych ekosystemów zajmuje powierzchnię 40371 ha. Vel'ká Fatra (Większa Fatra) z najwyższym szczytem Ostredok (1592 m n.p.m.) jest typowym obszarem górskim i zalicza się do najwyższych grzbietów górskich Słowacji. Charakterystyczne dla parku są ekosystemy trawiaste położone powyżej linii lasów (,hole” w języku słowackim), porastających $85 \%$ obszaru i wysokogórskie ukształtowanie terenu. Rozległe obszary trawiaste, usytuowane na lagodnie uformowanych grzbietach, są wynikiem wylesiania, które miało miejsce wiele wieków temu. Alpejskie łąki, bogate w zespoły rzadkich roślin, pokrywają powierzchnię 2000 ha. W przeszłości były wykorzystywane jako użytki zielone. Obecnie łąki nie są koszone. Powodem jest niewielka liczba przeżuwaczy w okolicznych gospodarstwach, wysoki koszt i uciążliwy transport na silnie zerodowanych drogach. Zakazano wypasu młodego bydła. W konsekwencji rozwinęły się zespoły wysokich traw, ruń została przerzedzona i zwiększyło się ryzyko lawinowe. Obecnie zezwala się ponownie na wypas młodego bydła, ale rolnicy nie korzystają powszechnie z tej możliwości. Wypasa się tam jedynie 200 jałówek i 2500 owiec jedynie w najniżej położonych terenach górskich przez krótki okres. Zespoły trawiaste są zdominowane przez Deschampsia caespitosa (L.) P. Beauv. i przez bardzo ekspansywne Calamagrostis epigejos (L.) Roth, Brachypodium pinnatum (L.) P. Beauv. and Cirsium arvense (L.) Scop., co wskazuje na wydłużony okres zaniechania użytkowania. 